\title{
Rural Finance, Capital Constrained Small Farms, and Financial Performance: Findings from a Primary Survey
}

\author{
Aditya R. Khanal ${ }^{\star}$ (1) and Omobolaji Omobitan \\ College of Agriculture, Tennessee State University, Nashville, TN, USA \\ *Corresponding author. Email: akhanal1@tnstate.edu
}

\begin{abstract}
Capital and credit constraints limit the small farm's ability to adequately use resources for optimum performance. Farmers' access to capital is constrained in multiple ways, including price factors, risk factors, and transaction factors, as well as access to and ease of rural agricultural financing. Using a primary survey data of small farms in Tennessee, we analyzed factors influencing credit constraint and its impact on farm performance. Farm operators' gender, off-farm work, land acreage holdings, farm specialization, and the use of smart phone with Internet significantly influenced credit constraint. We found that the financial performance of credit constrained small farmers was significantly lower than that of unconstrained small farmers-an adverse impact of constrained capacity to credit could result in up to $\$ 51,000$ lower in gross farm sales. Additionally, our reason-specific results within credit constraint suggested that around $\$ 32,000$ to $\$ 39,000$ lower performance in gross sales can be attributable to the constrained borrowing with deficit to obtain agricultural loans at required or desired level.
\end{abstract}

Keywords: Agricultural finance; constrained borrowing; credit constraint; financial performance; propensity score matching; rural credit in America; small farms; Tennessee

JEL Classifications: D13; Q12; Q14; Q18

\section{Introduction}

Agriculture, in most cases, requires a significant start-up investment to begin operations as well as to continue operations. Credit is one of the important factors in agriculture because it allows farmers to have access to capital and meet their obligations as required during various stages of the production cycle. Production in agriculture is peculiar to a production cycle involving a significant time gap between the input use and the output produced due to the biological processes, which are also subjected to whims of weather, pests, and diseases (Conning and Udry, 2005). In that, the feasibility of financial markets could complement by generating value through loans characterized by cash or goods exchange now with an undertaking of repayment in the future. This promise can be backed up with added limitations, which define the rights and behavior of the parties involved. However, this promise can occasionally be broken by the borrower. This imperfect information (asymmetry) situation has financiers evaluating prospective borrowers in order to decide who is likely to settle loans as promised. Financiers, on the other hand, follow up on which funds are used in order to confirm that they are used for activities that guarantee loan payment (Dowd, 1992; Von Pischke, 1991). From the farmers stand point, payment for materials and purchase of inputs such as seeds, fertilizer, and labor should be met, in most cases, readily through cash, liquid assets, or line of credit (if available) during the respective stages of preparation, planting, cultivation, and harvesting. Note that these payments are required to be completed during times when limited or

(C) The Author(s) 2020. This is an Open Access article, distributed under the terms of the Creative Commons Attribution licence (http:// creativecommons.org/licenses/by/4.0/), which permits unrestricted re-use, distribution, and reproduction in any medium, provided the original work is properly cited. 
no income is earned from agriculture, while most cash income from farming is earned typically after some time of crop harvest or livestock sale. In addition to the initial investment, farmers have challenges to meet liquidity requirements in the production process during time lag between planting and harvesting. However, with limited access to credit, the quantities and the combination of inputs used by the farmers might not be optimum, which may lead to suboptimal productivity and outcome. The marginal impact of sufficient credit, therefore, permits input level used to be close to the best level, hence increasing performance and output (Feder et al., 1990). In addition, agricultural financing is unique in that farming is a high-asset but low-income activity with relatively low return on investments. Agricultural consolidation and structural changes have increased the need for capital pushing farms to increase their sizes to maintain continued profitability.

It should be noted that agriculture is an important sector for rural economic development. Access to credit enhances farmers' abilities to adequately use resources in order to increase productivity and to purchase inputs to expand the scale of operation (Adera, 1995; Akwaa-Sakyi, 2013). Ahma (2010) argues that access to credit allows the farmers to venture into new areas of economic activities, increase their sources of capital, and manage risks associated with agriculture. As important as access to credit is for farmers, a number of challenges embody the adequate credit access at a competitive rate. Furthermore, lower return on investment causes limitations to undertake profitable investments or to take maximum advantage of market opportunities leading to reduced revenue and growth opportunities. High transaction costs attached to information gathering, strict collateral requirement, and credit history are important constraints affecting mostly small farmers as well as entrepreneurs (Boucher, Guirkinger, and Trivelli, 2009; Fletschner, Guirkinger, and Boucher, 2010; Guirkinger, 2008; Guirkinger and Boucher, 2008).

While we find a large number of studies on credit and rural financial markets focused in the context of developing countries, credit and rural financial problems are not an exception in developed countries. Blancard et al. (2006) found that credit and investment constraints were binding on French farmers' profit function-unconstrained farmers having access to financial markets performed significantly better. Moreover, in various studies analyzing U.S. agricultural finance context, scholars have found binding financial constraints on production and profit, such as, binding credit constraints (Lee and Chambers, 1986), binding cash flow constraints among New York dairy farmers (Tauer and Kaiser, 1988), binding credit constraints for some sampled California rice growers (Färe, Grosskopf, and Lee, 1990), and assets and debt constraints (Whittaker and Morehart, 1991). In a recent study, specifically analyzing new farmers' data from Alabama, Hartarska and Nadolnyak (2012) found evidence that the new farmers (those initiating operations after 2005) were significantly financially constrained. Moreover, Briggeman, Towe, and Morehart (2009) showed that production is lower by $3 \%$ in credit constrained farmers compared to credit unconstrained farmers in the United States.

Even though external financing is very common among farmers, there are several factors that hinder these farmers from obtaining finance. One important factor is the cost of external financing due to capital market imperfections as a result of information asymmetry between borrowers and lenders (Girante, Goodwin, and Featherstone, 2008) — transaction cost can also come in the form of loan application preparation, value of collateral evaluation, or credit use monitoring all of which can increase the overall cost of borrowing and can result in a wedge between effective interest rate and contracted interest rate. Also, the farmers may be afraid of losing their collateral as a result of the risky nature of the industry, hence they get discouraged from getting credit, even though the credit is needed and the market rate is favorable (Carter, 1988). An increase in interest rate resulting from an increase in demand for credit and imbalanced supply could also make some farmers credit constrained (Stiglitz and Weiss, 1981). Other factors may include the lack of assets used for collateral (Boucher, Guirkinger, and Trivelli, 2009), the limited supply of capital market, inadequate institutions to offer credit services, and demographic characteristics such as the education level of farmers. 
Access to credit and financial markets play an important role in rural American farmers' performance. Potential growth and development of rural areas in the United States have shown to have significantly strong links between agricultural lending (Hartarska, Nadolnyak, and Shen, 2015; Johnson, 2009). However, access to credit and proper functioning rural financial markets continues to be an issue, affecting new farmers and land values in the United States (Hartarska and Nadolnyak, 2012; Mishra, Moss, and Erickson, 2008).

Reviewing historical perspectives and genesis of America's farm credit system specifically in rural areas, Turvey (2017, p. 17) writes "spillover effects from the liberalization of financial markets has not, in many jurisdictions, provided the required spillover effects for institutional development in rural areas. Binding liquidity constraints limit farm profitability and investment, and even when there is access to credit collateral risk and risk-rationing can limit demand"; "despite great progress in developing capital markets, the promised development of institutional capacity and spillover effects into increased access and use of credit has not materialized in many jurisdictions."

Moreover, there is also segmentation in the rural financial market (Nadolnyak, Shen, and Hartarska, 2017). The major financial institutions-Farm Credit System (FCS) and commercial banks are considered the major lenders for agricultural loans in the United States-tend to serve well-equipped farmers with a high degree of credibility, while farmers with lower incomes with low-collateral ability face significant challenges. Bank market structure in the United States has been characterized by consolidation and mergers, where a limited number of financial institutions dominate the market; there are fewer and larger banks and FCS institutions (Dodson and Ahrendsen, 2017). Discussing the two parallel facts: (1) higher profitability of banks who are providing farm loans and (2) the higher demand for agricultural credit in farm-dependent counties possibly crowding out nonfarm demands, Kilkenny and Jolly (2005) postulate that banks providing farm credit may engage in credit rationing towards farmers and away from nonfarm borrowers. Commercial lenders focus on lending to larger commercial farms. Many smaller farms face difficulties as loan sizes requested by small farms may not be economical for commercial lenders. In this regard, Dodson and Ahrendsen (2016) discussed debt usage by small and large farmers, particularly noting that there has been a significant drop in debt held by farms with less than $\$ 100,000$ in production (a drop by $10 \%$ between 1996 and 2014), while debt held by larger farms with more than 2 million in production increased significantly (around 20\% between 1996 and 2014). Medium- and large-scale farmers have greater flexibility in regards to medium- and long-term credit financing, however making long-term investments by small farmers and entrepreneurs is usually very rare. This may prevent small farms from an introduction to new technologies, modernization of equipment, and provision of greater opportunities for profit, leading to inhibited growth and productivity. The Farm Service Agency (FSA)'s direct and guaranteed loans aimed at a specific class of borrowers has served small farms and farms with temporary financial difficulties to some extent through direct loans (Dodson and Ahrendsen, 2017). However, full functionality and sustainability of these direct programs to meet increased loan demands of small farms is debatable at least from two viewpoints-first, in the face of limited budgetary and staffing resources of FSA and second, overall policy level discussion about mainstreaming distinct credit mechanism of part-time, full-time, and beginning farmers (Dodson and Ahrendsen, 2017).

Small farmers do not have sufficient internal capital to fund their farm operations due to limited resources at their disposal. Access to sufficient credit is important for their farm operations (Dicken, 2007). Typically, a small share of small operations use debt to finance their operations, and the share of farms using structured farm debt increases with farm size (Harris et al., 2009). However, the overall demand for loans by small farms is increasing over the years as U.S. agriculture is characterized by a large number of small farms. Credit constraints have direct as well as indirect impact on farm productivity and efficiency. Directly, credit constraints can affect the farmer's purchasing power to buy inputs, fund operating expenditures in the short run as well as farm related investments decisions in the long run. Indirectly, it can affect the risk behaviors 
of farmers, which also influences the farmer's technology choice and adoption (Boucher, Guirkinger, and Trivelli, 2009; Eswaran and Kotwal, 1990). According to Binswanger and Deininger (1997), an imbalanced circulation of initial capital in the presence of imperfect financial markets with difficulty in credit access, specifically in immature credit markets, can prevent small farmers from making productive decisions and investments; the credit constrained farmer is more likely to invest in less risky and less productive rather than in riskier and more productive technologies (Dercon, 1996). This type of risk behavior limits the farmer's work and efforts from getting the optimum conceivable output. Moreover, the impact of credit constraints on productivity is well documented in the literature (e.g., Barry and Robinson, 2001; Blancard et al., 2006; Färe, Grosskopf, and Lee, 1990; Lee and Chambers, 1986; Petrick, 2005).

Although there are previous studies on credit access, impact, and efficiency, an updated review of rural agricultural finance and studies about the credit role, constraint, and actual impact on financial performance are limited, specific to small farms. There are no recent studies adequately addressing these aspects in Tennessee, which ranks 32nd among the states in the United States for total agricultural production and is listed as one of the economically competitive states in the country. In this study, we use small farms in Tennessee as an example to examine these issues using a primary survey. We have defined small farms as those operations with less than $\$ 350,000$ gross farm income, following farm typology definitions of the Economic Research Services (ERS, USDA).

Agriculture in Tennessee is dominated by small farms having less than $\$ 350,000$ gross annual farm income. Tennessee has around 69,983 farm operations with 10,900,000 acres of farm operated lands (Census of Agriculture, 2017). Tennessee has a strong crop, livestock, and poultry based agricultural production that contributes to the state's economy: In 2017, Tennessee's soybean, corn, wheat, and tobacco brought around $\$ 1,385$ million in cash receipts, while broiler poultry and hay brought $\$ 443.9$ million and $\$ 130.7$ million cash receipts, respectively (Census of Agriculture, 2017). Small farms contribute to the state's total production of agricultural commodities such as soybean, hay, broiler poultry, goats, hogs, cotton, and tobacco, as well as on the production of fresh marketable fruits and vegetables. Tennessee ranks third in the nation for fresh-market tomatoes and fourth in the nation for meat goat production (Tennessee Farm Bureau, 2019), predominantly produced by small farms. Noting the above statistics, it is evident how important small farmers are to Tennessee's economy as well as to the United States indirectly. However, 66,406 male and 26,054 female principal operators of 69,983 farm operations in Tennessee make on average of $\$ 10,911$ net cash farm income per operation-in terms of net cash farm income, only 3,798 operations indicated net annual gain of more than $\$ 50,000$, while 1,293 operations indicated net annual loss of more than $\$ 50,000$ (Census of Agriculture, 2017). While this fact is noteworthy, several factors may contribute to the differences in performance of the farm operations and operators, including demographic characteristics, farm size, technology adoption and use, income and enterprise diversification, debt/asset structures, and access to capital market.

Using the primary survey data from small farmers in Tennessee, we investigate whether credit constraint significantly affects financial performances. To examine this we: (a) assessed problems related to credit and loans of small farms, (b) assessed factors influencing credit constraint and the effect of each factor on the likelihood of the small farmer being credit constrained, and (c) estimated the impact of credit constraint on financial performance. Credit constraint implies that farmers either have access to partial credit or no credit access at all when credit is desired. This study hypothesizes that being credit constrained affects financial performance of these farmers as their capacity to fully fund resources for agriculture is limited, and they tend to use suboptimal inputs. This affects their level of productivity and gross sales. We have used gross farm sales as an indicator of financial performance in this study.

\subsection{A review of current government policies in rural financing}

The agricultural sector in the United States is characterized by a large number of small farms. Rural farmers, both small and large, requiring finance for their agricultural activities rely on rural 
financial institutions. However, the rural capital market is characterized by imperfections, including information asymmetries. The government intervenes in the agricultural capital market in several ways by making available guarantees to banks for loans, establishing credit organizations solely for agricultural purposes, and providing subsidies to farmers. The questions to be asked are: Are these programs set up as a result of failure in the capital market or as a result of pressure from people to provide subsidies for the agricultural sector? Do the policies resolve issues? Does it induce market distortion? If it induces market distortion, how can these distortions be quantified and do they have effect on efficiencies and incentives? In Section 1.1, we review agricultural financing and government support in the United States.

One important government intervention in the credit sector is the creation of specialized agricultural credit institutions such as the FCS, the FSA, and State Agricultural Development programs. The FSA provides finance to rural farmers through multiple loan programs and land contract programs ranging from guaranteed loans to direct loans. The FSA provides microloans, emergency loans, marketing assistance loans, farm storage facility loans, and rural youth loans for youths between 10 to 20 years to start and manage income generating plans. FSA also provides Noninsured Crop Disaster Assistance Program (NAP) for producers of non-insurable crops that do not qualify for federal crop insurance, which is a risk management tool intended to reduce financial losses in situations when natural disasters lead to a loss of production or prevent planting. In the currently defined plan, NAP covers losses exceeding $50 \%$ of projected production and $55 \%$ of average market price; up to $65 \%$ of projected production and $100 \%$ of average market price (USDA/ERS, 2017). FCS loan funds directly to individuals to purchase land and farm equipment, as well as for operations and insurance purpose (FCS, 2016). FSA's guaranteed and direct loans are aimed to provide loans for different segments of loan borrowers. Guaranteed loan somehow ensures conventional agricultural lenders such as commercial banks to entice them to underwrite riskier borrowers. However, it also has the mechanism to directly underwrite loans. FSA direct loans are primarily targeted at beginning farmers and small farmers with limited resources, including some portfolios to serve socially disadvantaged farmers, emergency loans, and economic emergency loans. Moreover, Federal Deposit Insurance Corporation (FDIC) insured institutions (commercial banks, savings associations, etc.) also provide agricultural loans. Looking at the recent composition of farm income and wealth statistics presented by the USDA, ERS (Farm Sector Balance Sheet, 2019), FDIC-insured institutions and FCS, each make up around $40-41 \%$ of all agricultural lending, the FCA makes around 3\%, and the rest (15-16\%) is by other institutions (such as life insurance companies, credit unions, and Farmer Mac, etc.).

\section{Conceptual and theoretical model}

Figure 1 explains the conceptual model defining credit constrained farmers. This conceptual diagram is adapted from Ali, Deininger, and Duponchel (2014). Figure 1 conceptually shows that an unconstrained farmer is one who applied for a loan, received the total amount applied and desired, and was satisfied. However, farmers can fall into capital (credit) constraint in several ways. The first scenario is that a farmer can apply for a loan and either get rejected or get partial approval. This implies that the quantity of the loan was rationed (quantity rationed). Hence, a farmer who did not receive the applied loan at all and a farmer who wanted more loan but did not receive as much as expected, are both credit constrained. The second scenario of credit constraint is that the farmer applied for a loan of a certain amount and was approved, but he/she would have liked to borrow more. The farmer did not ask/apply as desired due to factors such as high interest rate, lack of collateral, fear of losing collateral, fear of being rejected, and/or already too far in debt. The third scenario of being credit constrained is the farmer who did not apply for a loan but would have liked to. The farmer did not apply due to factors such as high interest rate, lack of collateral, lack of supplier, lack of information of where to apply, no bank account, not a member (in the case of a 


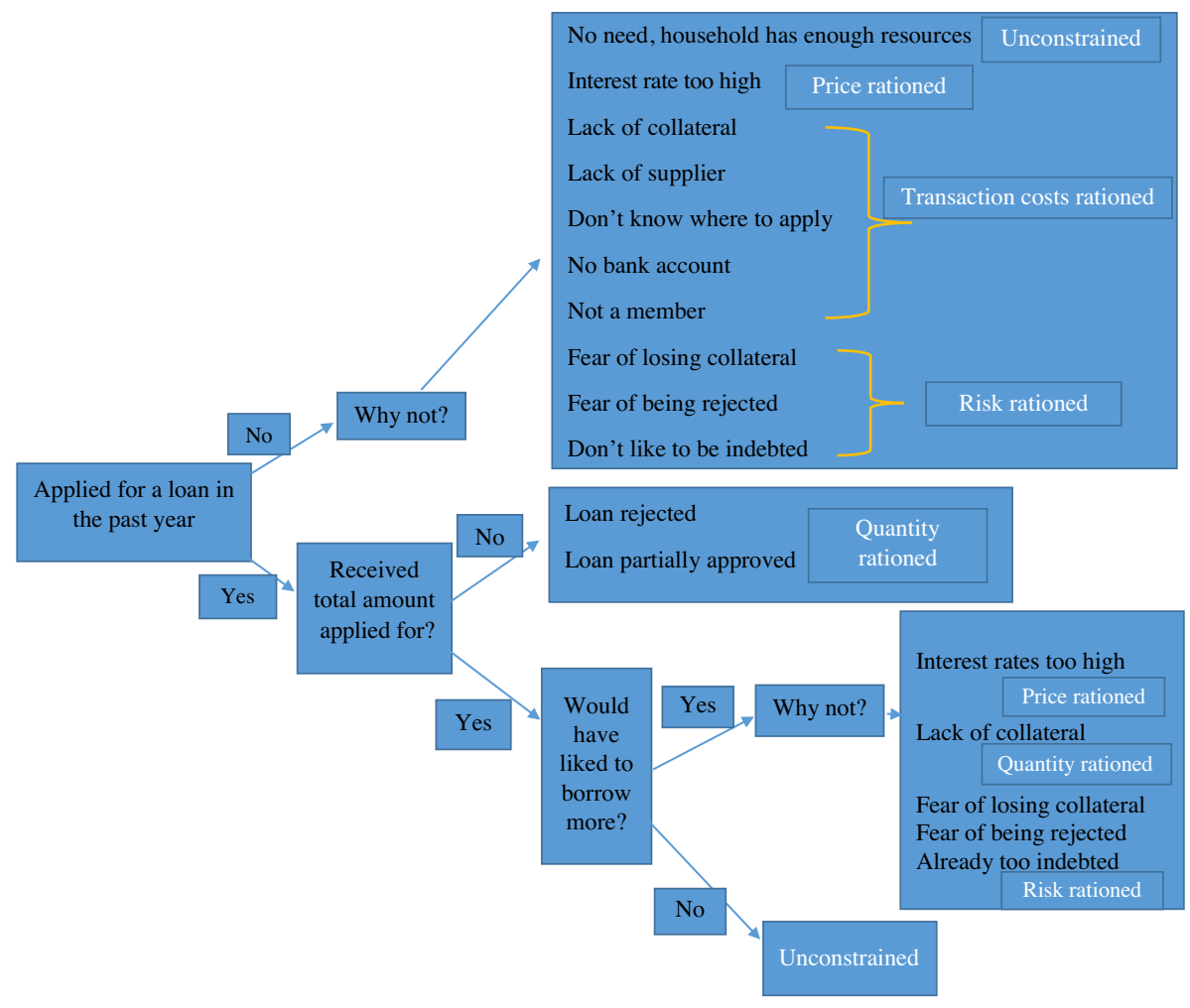

Figure 1. Showing the conceptual framework of credit constraint. Source: Ali, Deininger, and Duponchel (2014).

cooperative), fear of losing collateral, fear of being rejected, etc. In summary, a farmer can be credit constrained due to price factor, risk factor, or transaction cost factor (Bethuel, 2018). Capturing these different aspects in the credit constraint definition is important. Specifically, the second and third scenario is in line with the essence of "discouraged borrowers" as referred to in Jappelli (1990, footnote 2), who indicated that completely "omitting this group may lead to biased estimates of the probability that consumers are credit constrained." Therefore, we have tried to capture the essence of discouraged borrowers in our definition of credit constraint (our definition of credit constraint variable is described in Section 5.1). Moreover, in the discussion of credit markets in the United States and consumers in general, Jappelli (1990) showed that both consumer and lender characteristics ${ }^{1}$ determine the probability of credit rationing.

The theoretical framework presented below and used in this study links farmer's credit access with farm performance. This model conceptualizes that the receipt of credit enhances the net revenues attainable from resources and market prospects, it derives the model via farmers' maximization of utility of net revenue (NR). Productivity and efficiency differences among farmers can be due to binding credit constraints. Following Khanal and Regmi (2018), assume a farm household with existing land $L$ and nonland variable inputs (such as labor, fertilizer, seed, and other) captured in $X$. The farm production function can be represented as $f\left(X, L, Z^{q}\right)$ where $Z^{q}$ is the vector

\footnotetext{
${ }^{1}$ We reviewed the factors used in Jappelli (1990)'s empirical model dealing with general consumers in the credit market. Our empirical model includes some factors discussed in Jappelli's model while leaving others because we are limited by the availability of variables in our primary survey data typically constrained by assessment of assets as faced by low or no response on information asked on farm household's assets and wealth related questions; we have used a land acreage holding variable, one of the important components of asset/wealth of a farm household.
} 
of production shifters. Assuming $p$ and $w$ are the market price per unit for output and inputs, respectively, the farm's $N R$ can be represented as:

$$
N R=p f\left(X, L, z^{q}\right)-w X
$$

Let us assume that the farm has some income level $Y$ at the beginning of the process of production. The farmer allocates $C$ for consumption with unit price, $p$. If $Y \geq p C+w X$, then the farmer can self-finance consumption and production events and is able to get a maximal $N R$ level without using external financial resources. However, in most circumstances, farmers have the ability to pay only a fraction of production and consumption expenditures from their own income. ${ }^{2}$

Assume that the farmer is able to pay only fraction $s$, with $0<s<1$ of variable inputs. Then the $(1-s)$ portion of variable inputs should come from outside financing-typically loaned from either formal or informal lenders. Lenders will determine the credit, $K$, to grant to the farmer charging the interest rate on the requested loan. Under these circumstances and the model assumptions, the farmer's problem is to maximize the utility of profit $U(N R)$ as follows:

$$
\operatorname{Max} U[N R(X)]=U\left[p f\left(X, A, z^{q}\right)-s w X-(1-s) w X\right]
$$

Subject to:

$$
\begin{gathered}
(1-s) w X \leq K\left(z^{c}, z^{q}\right)+(Y-p C-s w X) \\
0 \leq K\left(z^{c}, z^{q}\right) \leq \rho A
\end{gathered}
$$

The equations show that the expenses on variable inputs $X$ are restricted by the farmer's initial income $Y$, consumption expenditures $p C$, and the credit limit, $K\left(z^{c}, z^{q}\right)$. The maximal quantity of credit available to the farmer can be determined by both production characteristics, $z^{q}$, as well as consumption shifters, $z^{c}$ (factors influencing consumption such as household size, financial condition, and wealth). Additionally, equation (4) shows that the farmer's credit limit constraint is determined by the value of asset owned ( $A$ having unit price $\rho$ ). The optimality condition for this is obtained by first order conditions. As derived and shown in Khanal and Regmi (2018) under the binding credit constraint condition, a lower optimal level of input demanded by the farmers implies a higher credit constraint - a sub-optimal production leading to sub-optimal financial performance.

\section{Econometric framework}

Consistent with our theoretical and conceptual model, we used econometric methods to empirically test the hypotheses and estimate: (a) the relationship of credit constraint with a set of socioeconomic and demographic variables including access to information and perceived risk of the farm and marginal likelihood of being credit constrained, and (b) the impact of credit constraint on financial performance. To accomplish these, we used: (a) probit model where credit constraint is the dependent variable with different factors influencing credit constraint, and (b) the propensity score matching (PSM) estimator to approximate and quantify the impact of credit constraint on financial performance of small farms.

\subsection{Probit model}

Our model to estimate determinants of credit constraint in multiple regression frameworks can be shown in generic form as:

$$
y=f\left(X_{1}, X_{2}, X_{3}, X_{4} \ldots \ldots \ldots X_{n}\right)
$$

\footnotetext{
${ }^{2}$ Specifically, the U.S. commercial family farm households not under production contracts are shown to have lower income but higher assets and tend to fund operations through a combination of income and working capital (including financial assets and inventories). However, for the simplicity and generality in our theoretical conceptual model, we maintain household consumption and farm operational expenditures met by proportion of income $Y$.
} 
where the dependent variable $y$ is the credit constraint and $X_{1}, X_{2}, X_{3}, X_{4} \ldots \ldots \ldots X_{n}$ represents a set of independent variables influencing the farmer's likelihood of being credit constrained. Credit constraint is a binary variable having the value 1 if credit constrained and 0 if not. Due to the nature of the dependent variable, a nonlinear model is appropriate to estimate the relationship. The most widely used methods are probit and logit as these methods effectively transform the regression model so that the fitted values and estimated probabilities lie between $(0,1)$ interval (Gujarati, 2009). The logit and probit are comparatively the same in most applications, the key difference between the two is due to the nature of their distribution, which is accounted for by the Cumulative Distribution Function (CDF). Probit takes a normal distribution, while logit has a logistic (slightly flatter tails) distribution. The choice of probit versus logit regression depends, therefore, chiefly on the distribution assumption one makes. Following the majority of agricultural economic studies, we assume standard normal distribution of the error term and choose probit method to estimate our model and compute marginal effects. Probit is a nonlinear model estimated using the maximum likelihood method (for detail, see, e.g., Gujarati, 2009). The marginal effect is defined as the effect a unit change in each independent variable $(x)$ used in the study has on being credit constrained which is the outcome variable $(y)$. In generic terms, Marginal $e f f e c t=d y / d x$. In case of the probit model, marginal effect is generically shown as (Cameron and Trivedi, 2010):

$$
\text { Marginal effect }{ }_{\text {probit }}=\frac{\partial y}{\partial x_{j}}=\beta_{j} \emptyset\left(x^{\prime} \beta\right),
$$

where $\beta_{j}$ is the coefficient on variable $x_{j}$ from probit regression and $\emptyset($.$) denotes the standard$ normal density.

\subsection{Propensity score matching estimator}

The PSM estimator estimates the effect of treatment that is given to a group in the presence of a counterfactual control group. The mean or mean-based estimates such as OLS provide a biased and inconsistent estimate if there is the presence of selection bias. In our case, we need to account for selection bias because assigning the surevy respondent to the treatment (credit constraint) is not random and credit constrained farmers are likely to have characteristically different from unconstrained (Briggeman, Towe, and Morehart, 2009). PSM is suggested as an appropriate method (Abadie and Imbens, 2002; Abadie and Imbens, 2011) to compute more accurate impacts controlling for selection bias in nonexperimental settings (Abadie et al., 2004; Abadie and Imbens, 2011; Dehejia and Wahba, 2002; Rosenbaum and Rubin, 1984). PSM has been increasingly used in recent agricultural economics studies aiming to estimate causal effects using cross-sectional data (Briggeman, Towe, and Morehart, 2009; Joo, Khanal, and Mishra, 2014; Khanal and Mishra, 2016; Khanal, Mishra, and Koirala, 2015; Mendola 2007; Sitienei, Mishra, and Khanal, 2016; Verhofstadt and Maertens, 2014). PSM is based on balancing the distribution of observed attributes ${ }^{3}$ of credit constrained and credit unconstrained farmers and computing difference after matching based on observed attributes - discovers a counterfactual or matching propensity based on the set of covariates. Since similar groups are formed conditional on their basic characteristics, PSM assumes that the only factor that causes the performance difference between treatment and control counterfactual group after matching is the treatment variable, referred to as the assumption of "ignorability," "selection on observables," or "unconfoundness" (Briggeman, Towe, and Morehart, 2009; Imbens, 2004; Uematsu and Mishra, 2012). Although we cannot directly test this assumption, empirical studies test the balancing between observed distribution of covariates across treatment and control groups after matching to ensure no systematic differences between distributions and to examine overlap

\footnotetext{
${ }^{3}$ Since PSM is based entirely on observed attributes, a general limitation is that PSM may have biased results in the presence of certain unobserved variables affecting both treatment (credit constraint) and outcome variables.
} 
(common support) of covariates. The balancing property can also be tested with mean absolute standard bias (MASB) between credit constrained and unconstrained farmers (Rosenbaum and Rubin, 1985). A MASB below $20 \%$ is generally suggested to qualify the matching process. Additionally, pseudo $R^{2}$ and $P$ values of likelihood ratio of joint insignificance from logit/probit models before and after matching can be evaluated for matching quality (Sianesi, 2004).

PSM is applied in two steps: the first step is that a probit model is estimated with the binary treatment variable (credit constrained or unconstrained status of farmers). Starting with this first stage of regression, the PSM evaluates the propensity scores of each observation. The propensity score of each farmer measures his or her tendency to be credit constrained. The magnitude of a propensity score is between 0 to 1 ; the larger the score, the more likely the farmer is credit constrained. The second step, based on estimated propensity scores, two balanced groups are formed. Note that the balancing is based on the likelihood of being credit constrained, as explained through farm performance factors. Farmers in each group have like propensity scores. The two groups can then be compared in regard to their performance based on several matching methods such as "nearest neighbor matching," "radius based matching," or "kernel based matching." The difference in the performance between the matched treated and control observations follows a $t$-test for statistical significance. By calculating probabilities from a first-stage probit and then forming the treatment and control groups based on these probabilities, PSM minimizes the selection bias that might have existed in the observed data.

\section{Sampling procedure and data collection}

Primary data were collected from Tennessee farmers through a structured questionnaire, which was administered by sending a survey link via e-mail. An electronic survey method was chosen because it is considered to be cost effective and quick to administer. Survey and personal interview methods are expensive and slow (Dillman, Smyth, and Christian, 2009). To achieve a highresponse rate from online correspondences, e-mail reminders were sent three weeks after the survey was sent, followed by second and third reminders at two-week intervals after the first reminder. In total, each farmer received at least three reminders and sometimes even more, depending on their response time. This is in line with the study by Dillman (1991) that repeated contacts often increase response rate.

Contact information for farmers are collected by extracting e-mail addresses and phone numbers obtained from the Pick Tennessee Products organization database. ${ }^{4}$ The Pick Tennessee Products database has various categories of producers representing different agricultural enterprises such as fruits, vegetables, herbs and mushroom, honey, meats, poultry ${ }^{5}$ and eggs, dairy, certified organic, as well as agritourism. The database included east, west, and middle regions and was also further categorized based on counties in Tennessee. The total number of farmers' e-mail addresses and contacts were extracted using a stratified random sampling method based on counties, as well as different categories among the agricultural farms listed. In total, we sent the survey to 720 farms: 250 to the east, 250 to the middle, and 220 to West Tennessee in 2017 and received 104 responses. The questionnaire was pre-tested to evaluate the validity and clarity and to evade repetitive questions by sending the questionnaire to a small subsample of contacts (those not in the selected 720) in West Tennessee to observe their responses and modify some questions.

\footnotetext{
${ }^{4}$ Our stratified randomization is among the farms listed in the Pick Tennessee database. Although we made an effort to have a representative sample of Tennessee farms, we acknowledge and provide a cautionary note that some limitations regarding representation may exist because picked farm operations were maintained in the database. Picked farm operations most likely include operations directly or indirectly involved, participating in, or in contact with the Pick Tennessee mission of the Tennessee Department of Agriculture.

${ }^{5}$ Broiler poultry production is generally under production contracts in Tennessee, typically for large commercial farms. However, we cannot distinguish whether farms in our sample were operating under production contracts because a question related to contracts was not asked in the questionnaire.
} 
Table 1. Summary statistics of variables used in the study

\begin{tabular}{|c|c|c|c|c|c|}
\hline Variable & Variable Definitions & Mean & Std. Dev. & Min. & Max. \\
\hline Grosssale & $\begin{array}{l}\text { Annual gross sales from agricultural enterprises (including } \\
\text { agritourism incomes, if involved) }\end{array}$ & 43,900 & $55,316.3$ & 0 & 350,000 \\
\hline Cred_cons & Whether farmer is credit constrained (=1 if constrained) & 0.59 & 0.5 & 0 & 1 \\
\hline Age & Age of principal operator (years) & 53.29 & 10.38 & 34 & 68 \\
\hline Educ & Education of principal operators (years) & 14.06 & 2.79 & 5 & 18 \\
\hline Male & Gender of principal operator ( $=1$ if male) & 0.68 & 0.47 & 0 & 1 \\
\hline LnHHinc & Gross annual household income (in U.S. dollars, in log) & 11.03 & 1.07 & 3.2 & 12.15 \\
\hline LnAcres & Agricultural land acreage holdings (in log) & 2.45 & 3.07 & -1.38 & 6.68 \\
\hline Off-farm work & $\begin{array}{l}\text { Off-farm work participation ( }=1 \text { if operator or spouse work } \\
\text { off-farm, off-farm hours/week }>0)\end{array}$ & 0.43 & 0.48 & 0 & 1 \\
\hline Smartphone & $\begin{array}{l}\text { Use of smart phone with internet access } \\
\text { (=1 if smartphone) }\end{array}$ & 0.84 & 0.37 & 0 & 1 \\
\hline Continueplan & $\begin{array}{l}\text { Expected to continue farming in next } 5-10 \text { years } \\
(=1 \text { if continue plan) }\end{array}$ & 0.85 & 0.36 & 0 & 1 \\
\hline Specialized & $\begin{array}{l}=1 \text { if operation gets more than } 50 \% \text { of agricultural } \\
\text { production from one enterprise }\end{array}$ & 0.60 & 0.49 & 0 & 1 \\
\hline Cred_satisfied & $\begin{array}{l}\text { Familiarity and satisfaction level with existing ag loan } \\
\text { mechanism in Tennessee }\end{array}$ & 1.22 & 0.89 & 0 & 2 \\
\hline Divers_score & Agricultural enterprises diversification (score index) & 2.35 & 1.23 & 0 & 9 \\
\hline Riskprep & Farming operation's level of risk perception & 3.1 & 1.18 & 0 & 5 \\
\hline \multicolumn{2}{|c|}{ Number of observations } & 100 & & & \\
\hline
\end{tabular}

\section{Results and discussion}

\subsection{Descriptive statistics}

Table 1 presents summary statistics of the dependent and independent variables used in this study. The sample used for the analysis consisted of 100 observations, omitting 4 responses that indicated $>350,000$ in gross farm income, from the 104 survey responses obtained. Variable description, mean, standard deviation, minimum value, and maximum value are shown in Table 1.

Annual gross sales (or gross farm income from agricultural activities in farm types such as those involved in agritourism) is measured in U.S. dollars. The annual mean gross sale in our sample is $\$ 43,900$ with a standard deviation of $\$ 55,316$, which indicates that the majority of small farms are very small (Table 1). A larger standard deviation also suggests that there is a wider range of gross sales within the small farms. Further looking at the distribution of gross sale (gross income) variable, our data shows that $92 \%$ of sampled households generate below $\$ 100,000$ gross sales while only $8 \%$ generate between $\$ 100,000$ to $\$ 350,000$. This indicates that Tennessee has a vast majority of very small to moderately small farms within the categories of small farms. Mean gross sales (incomes) in our sample is comparable with recent Tennessee Census data (Census of Agriculture, 2017), which shows that the largest portion among farmers were dominated by very small farmers-out of 69,983 operations, remarkably high 65,701 (93.8\%) farm households generate farm sales below $\$ 100,000$, followed by 1,639 (2.3\%) generating $\$ 100,000$ to $\$ 250,000$; only $1,632(2.3 \%)$ operations have farm sales above $\$ 500,000$.

In our study, the credit constraint variable is represented as a dummy variable, where 1 implies being credit constrained, and 0 implies not constrained. According to the conceptual framework 
shown in Figure 1 and Bethuel (2018), a farmer can be credit constrained due to various reasons such as quantity rationing, transaction cost rationing, or risk rationing. Quantity rationing constraints occur from both the demand and supply sides. On the demand side, this occurs when the farmer is unable to make available quality and quantity of collateral required by the lender. On the supply side, however, this issue arises as a result of the lenders' unwillingness to increase interest rates to clear out excess demand (Stiglitz and Weiss, 1981). Given our primary survey data and response and keeping the view from previous studies about multifaceted ways of credit constraint, we defined credit constraint variable following a similar theme and somehow capturing the essence of "discouraged" or hesitant (Jappelli, 1990) borrowers (farmers) in loan or lending mechanism. Specifically, we defined credit constraints in this study: (1) if the farmer indicated any difficulty in obtaining agriculture-related loans, (2) if indicated "not being able to get loans as required or desired level for farm operation," and (3) if the farmer indicated that she/he had applied for agricultural loans and felt the following challenges or was hesitant to apply due to any of the following challenges: (a) high interest rate, (b) complicated procedures and paperwork to apply, (c) collateral requirements are problematic, (d) few institutions providing ag loans in rural areas, (d) lack of established line of credit, (e) no loan provided due to uncertainty in agriculture, or (f) no information about where to get loans. From Table 1, our study shows that more than half of our respondents (approximately 59\%) are credit constrained, following this definition. Figure 2 shows the breakdown of the response for each of these reasons of credit constraint. Credit constrained farms consisted of $30 \%$ farms that applied for agricultural loans and faced some sort of difficulties, $28 \%$ farms that did not obtain the loan as desired or required level, and around $42 \%$ either hesitated to apply in the face of the challenges mentioned earlier or experienced these challenges considering application (Figure 2).

We collected information on some demographic and farm-specific characteristics of sampled farm households. As shown in Table 1, our sampled farm households were dominated by male operators (68\%) with an average age of 53 and 14 years of education and had around $\$ 55,930$ of average annual household income. Around $43 \%$ of sampled farm household's operator or spouse were engaged in off-farm works. We have included farm land acreage holdings in our models as an indicator of a farm asset. Farm land acreage holdings ranged from as low as 0.25 acres to as many as one hundred acres of land, $60 \%$ of the farms had specialized production (more than $50 \%$ of agricultural production coming from one agricultural enterprise), and $85 \%$ of farms plan to continue farming over the next 5 to 10 years. Looking at the types of specialized farms in our data, it shows that fruits and nuts, poultry and egg, and vegetable dominated farms (with $>50 \%$ share) were the highest (each around 15\%) followed by goat farms (5\%).

Around $84 \%$ of sampled households used a smartphone with Internet access for their agricultural activities. A large percentage of sampled households owned and used a smartphone with Internet access, probably because $51 \%$ of principal operators in the survey were below 54 years -relatively younger principal operators tend to use modern technologies. We also asked about the respondent's familiarity and satisfaction level with the existing agricultural lending mechanism and the rural financing in Tennessee. An average of 1.22 on the 0 to 2 rating suggests that the higher proportion of respondents indicated familiarity and satisfactory level.

Our enterprise diversity score variable indicates the number of enterprises adopted (with at least $5 \%$ of agricultural production coming from each enterprise). The score ranged from 0 to 9, indicating that up to 9 enterprises were adopted by sampled farm households. A higher diversification score implies higher agricultural enterprise diversification. On average, small farmers adopted 2 agricultural enterprises. Finally, we included a variable related to "risk perception" of the operation, by asking "considering your farm operation's overall performance and challenges, how do you rate your operation's level of risk?” The risk perception variable ranges on a scale of very high (5), high (4), moderate (3), low (2), very low (1), and no (0). On average, sampled households indicated a moderate level of risk perception with a mean value of 3.1 (Table 1). 


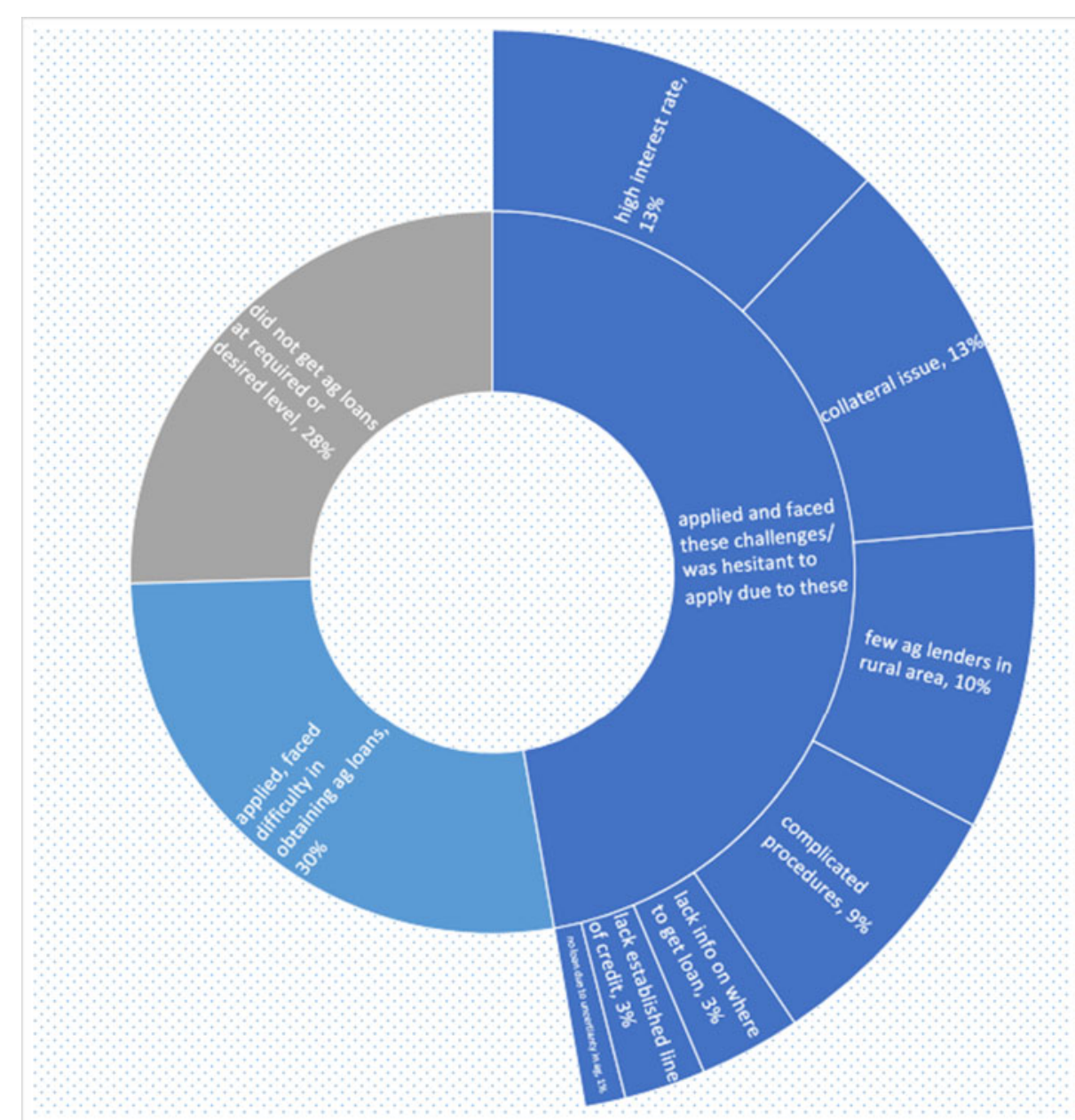

Figure 2. Distribution of credit constrained small farm households by credit related response, Tennessee, 2017. Source: Primary Survey.

\subsection{Results from econometric analyses and tests}

We examined two research questions through econometric analyses: first, credit constraint and factors influencing credit constraint and second, impact of credit constraint on financial performance (gross sales). ${ }^{6}$

\subsubsection{Probit regression results: Factors influencing credit constraint}

Table 2 shows the probit regression result of the factors that determine small farmers' likelihood of being credit constrained. Overall, the model is significant as indicated by the chi-square statistic value of 40.43 ( $P$ value 0.0001 ), and a good model fit indicated by pseudo $R^{2}$ of 0.41 . Particularly, a

\footnotetext{
${ }^{6}$ The first test we did is the two-sample $t$-test for mean comparison of gross sales, our financial performance indicator, between credit constrained and unconstrained groups. The test suggests a statistically significant difference in gross sales between these groups (mean gross sales for credit constrained households were $\$ 36,465$, while those of credit unconstrained were $\$ 54,167$ ). However, the mean comparison cannot be interpreted as impact as it does not account and control for several characteristic differences that are apparent between credit constrained and unconstrained farms. In Section 5.2.1, we present results from the PSM estimator, which overcomes this limitation by appropriately computing impact.
} 
Table 2. Results of probit regression and marginal effect of the determinants of credit constraint

\begin{tabular}{|c|c|c|c|c|}
\hline Variables & Coefficient & Marginal Effect & $z / t$-score & $P$ value \\
\hline Age of primary operator & -0.015 & -0.005 & -0.64 & 0.520 \\
\hline Education of primary operator & -0.022 & -0.008 & -0.31 & 0.757 \\
\hline Gender of primary operator: Male & $-1.035^{\star \star}$ & $-0.310^{\star \star}$ & -1.93 & 0.05 \\
\hline Household income, in log & 0.311 & 0.107 & 1.16 & 0.247 \\
\hline Agricultural land acres & $-0.229^{\star}$ & $-0.079^{\star}$ & -1.67 & 0.100 \\
\hline Off-farm work & $-1.153^{\star \star \star}$ & $-0.398^{\star \star \star}$ & -2.58 & 0.010 \\
\hline Smartphone with internet access & $-1.191^{\star}$ & $-0.307^{\star}$ & -1.78 & 0.076 \\
\hline Continuation plan & 1.043 & 0.395 & 1.47 & 0.142 \\
\hline Specialized operation & $-0.862^{\star}$ & $-0.275^{\star}$ & -1.73 & 0.083 \\
\hline Familiarity and satisfaction level & $-0.924^{\star \star \star}$ & $-0.319^{\star \star \star}$ & -3.31 & 0.001 \\
\hline Ag enterprise diversity score & 0.054 & 0.019 & 0.31 & 0.760 \\
\hline Risk perception & -0.01 & -0.067 & -0.05 & 0.962 \\
\hline Constant & 1.64 & & 0.46 & 0.642 \\
\hline \multirow[t]{3}{*}{ Overall model significance and model fit } & Pseudo $R^{2}$ & & 0.41 & \\
\hline & LR-chi-square (12) & & 40.43 & \\
\hline & Prob > chi-square: & & 0.0001 & \\
\hline
\end{tabular}

Note: Asterisks $\left({ }^{\star},{ }^{\star \star}\right.$, and $\left.{ }^{\star \star \star}\right)$ denote significance at the $10 \%, 5 \%$, and $1 \%$ levels, respectively.

relatively higher 0.41 of pseudo $R^{2}$ (for nonlinear models like probit) indicates a well explanatory power of independent variables included in the model. We found that demographic, socioeconomic, and farm-related variables, namely gender, off-farm work participation, land acreage holdings, use of a smartphone with Internet access, specialized production, and level of satisfaction with existing credit institutions in Tennessee significantly influenced credit constraint. The magnitude of the relationship of each independent variable with dependent variables is computed and presented as marginal effects. In other words, the marginal effect of the respective variable presents the variable's contribution on the likelihood of being credit constrained.

Our results in Table 2 show a significant gender effect on credit constraint. A negative coefficient and marginal effect of gender in Table 2 suggests that if the principal operator of the farm is male, he is less likely to be credit constrained (5\% level of significance). The magnitude of marginal effect suggests that the likelihood of credit constraint is 0.31 points (31\%) lower for male operators as compared to female operators. This finding is consistent with previous studies that found a positive impact for a male farmer to credit access as males are described to have more involvement in farming, have a higher probability of owning resources such as land which can be used as collateral in accessing loans (Bembridge, 1984; Dlova, Fraser, and Belete, 2004). Moreover, a significantly negative coefficient of land acreage holding variable suggests that farm households with large acreage holdings are less likely to be credit constrained. Farm land is an important asset and the relationship is consistent with our expectation. Marginal effects show that the likelihood of credit constraint decreases by $8 \%$ with additional acres of farm land holdings.

Another variable strikingly significant is the engagement in off-farm work. Operator or spouse's off-farm work participation decreases the likelihood of being credit constrained by around $40 \%$. The negative relationship is expected because off-farm work and generated income is expected to provide farmers with quick liquid capital to offset their debt (Barrett, Reardon, and Webb, 2001; Reardon, Crawford, and Kelly, 1994) making them less credit constrained. 
Additionally, a farmer's off-farm work participation may improve the likelihood of loan repayment because the farmer having off-farm income does not likely divert a loan meant for agricultural activities to other purposes since those expenses will be taken care of by earnings from an offfarm income (Ojiako and Ogbukwa, 2012). Additionally, we found that ownership of a smartphone with Internet access decreases the likelihood of being credit constrained (results are significant at the $10 \%$ level). This is plausible because a farmer who uses a smartphone with Internet access has the ability to track market and loan information. Farmers who use smartphones with Internet access could obtain first-hand information about where and how to get a loan (Ayamga, Sarpong, and Asuming-Brempong, 2006). Smartphone and Internet access enhance abilities to get farm related news and information, better and quicker communication, and access to the market that may reduce information asymmetry (Khanal and Mishra, 2016). Smartphones with Internet allow use and access to social media and may help to engage as a customer of the bank community and make arrangements for low-volume loans for disaggregated networks in the rural counties.

Also, our results suggest that specialized farm operations with more than $50 \%$ of agricultural production from one enterprise are less likely credit constrained, as compared to other farm operations. One plausible reason is that farms with specialized operations have specific capital, equipment, and production infrastructure and perhaps seem better in collateral ability for lenders. Finally, consistent with our expectation, if a farm operator is familiar and satisfied with existing rural financial institutions in Tennessee, the likelihood of being credit constrained decreases by $0.32^{7}(32 \%)$, and this result is significant at $1 \%$ or higher levels.

\subsubsection{Impact of credit constraint on financial performance: Propensity score matching estimator results}

We estimated the impact of credit constraint on financial performance using an appropriate PSM method, as described in Section 3.2. The estimated impacts are presented in Table 3. PSM computes impacts by creating appropriate counterfactual based on propensity scores and accounting for self-selection bias. This way, it enables the computation of the appropriate impact due to treatment (in our case, credit constraint) through measures such as average treatment effects for treated (ATT). Propensity scores were computed using the same set of covariates as the probit model. For the robustness of our findings, we used three different matching methods to compute the ATT, namely, nearest neighborhood matching (NNM), radius based matching (RBM), and kernel based matching (KBM). The matching procedure for each matching algorithm (NNM, RBM, KBM) were tested for balancing property. Figure 3shows treated on-support, treated off-support, and untreated regions. "Treated: On support" category includes credit constrained farmers with suitable matching pairs, which indicates the overlapping of distribution of propensity scores (common support) for credit constrained and unconstrained farmers. Observations in common support regions have comparable propensity scores, which we use in PSM to create a counterfactual group. Table A1 of the Appendix shows the covariate characteristics before and after matching, which show a significant reduction in the selection bias (percentage bias) in each covariate after matching. Mean of each covariate after matching between treated and control groups in mean comparison test is shown to be nonsignificant by $P$ value-indicating the treatment and counterfactual were alike after the match (Table A1). Additionally, pseudo $R^{2}$ and $P$ value of the likelihood ratio became statistically nonsignificant, indicating that there is no difference in observed attributes for these subsamples after matching (Table A2). Low bias values after matching, lower than the threshold of $20 \%$ for all matching algorithms (Rubin, 2008), indicates that the balancing property is satisfied.

\footnotetext{
${ }^{7}$ Since the survey has a 0 to 2 rating based on familiarity and satisfaction level for existing agricultural credit/loan mechanism as one question, this coefficient is a combined effect of familiarity and satisfaction and hard to separate. We acknowledge this limitation from the design of the question.
} 


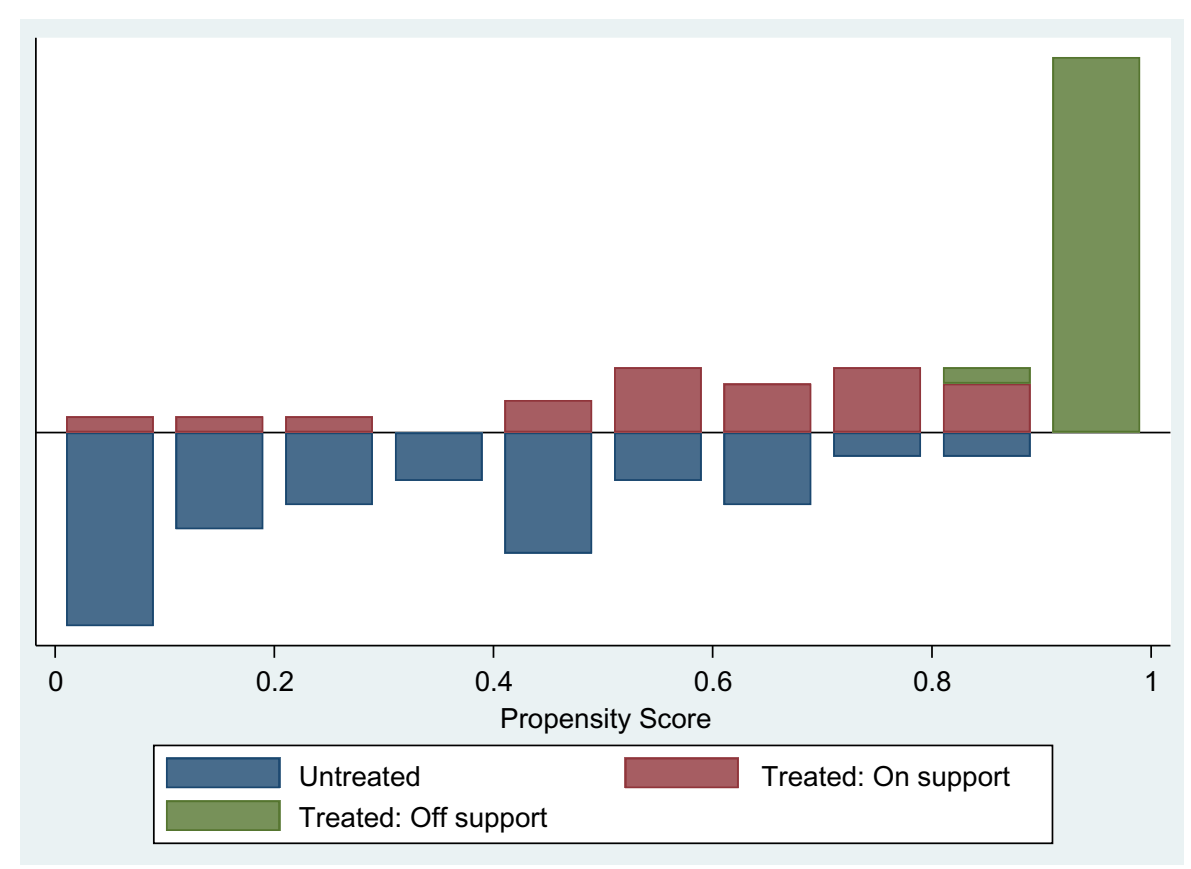

Figure 3. Common support and propensity scores for treated and untreated.

Notes: "Treated: On support" includes credit constrained farmers with suitable matching pairs. "Treated: Off support" includes credit constrained farmers for whom algorithm could not find matching pairs.

In each estimation presented in Table 3, we found differences in financial performance between credit constrained and their counterfactual counterparts-ATT estimates are significantly different and can be attributed as the impact solely due to credit constraint. Our financial performance measure, annual gross sales, of credit constrained farmers using NNM is $\$ 26,875$, while that of credit unconstrained farmers is $\$ 78,312.50$ with a difference in annual gross sales of $-\$ 51,437.50$. The difference is statistically significant at the $1 \%$ level or higher. Using Radius Based Matching (RBM), the annual gross sales of credit constrained farmers is $\$ 41,627.91$, while that of credit unconstrained farmers is $\$ 62,000$ with a difference in annual gross sales of $-\$ 20,372$ - the difference is statistically significant at the $1 \%$ level or higher. Finally, using Kernel Based Matching $(\mathrm{KBM})$, the annual gross sales of credit constrained farmers is $\$ 27,109.19$, while that of credit unconstrained farmers is $\$ 76,976.71$ with a difference in annual gross sales of $-\$ 49,867.52$. The difference is statistically significant at the $5 \%$ level or higher. These difference between treated and control is average treatment effects considered as the impact attributable to credit constraint.

\subsubsection{Constrained borrowing and the impact on financial performance}

We further estimated specific impacts relating to different situations/reasons within credit constraint. Specifically, Figure 2 clearly shows two groups of credit constrained farmers that can be referred to as "constrained borrowers": (a) those who applied for agricultural loans but faced some difficulty in the process (constrained borrowing 1), and (b) those who did not get agricultural loans as required or desired level (constrained borrowing 2). We separately examined the impact of these constrained borrowing on the financial performance. The estimated ATT impact are presented in Table 4 . Table 4 shows that the impact of constrained borrowing 1 on gross sales is not statistically significant between the treated and control groups. However, the impact of constrained borrowing 2 is noticeable and statistically significant between treated and control groups. Our ATT estimates on the impact of constrained borrowing 2 (Table 4 lower panel results based on NNM, RBM, and $\mathrm{KBM}$ ) suggest that around $\$ 32,000$ to $\$ 39,000$ lower in gross sales compared to unconstrained 
Table 3. Impact of credit constraint on financial performance (gross sales) of small farmers

\begin{tabular}{lcccc}
\hline \multirow{2}{*}{ Method } & \multicolumn{4}{c}{ Average Treatment Effects (ATT) } \\
\cline { 2 - 5 } & Treated (in \$) & Controls (in \$) & Difference (in \$) & $t$-stat \\
\hline Nearest neighborhood matching (NNM) & $26,875.00$ & 78312.50 & $-51,437.50^{\star \star \star}$ & -2.60 \\
\hline Radius based matching (RBM) & $41,627.91$ & $62,000.00$ & $-20,372.09^{\star \star \star}$ & -2.58 \\
\hline Kernel based matching (KBM) & $27,109.19$ & $76,976.71$ & $-49,867.52^{\star \star}$ & -2.41 \\
\hline
\end{tabular}

Note: Asterisks $\left({ }^{\star},{ }^{\star \star}\right.$, and $\left.{ }^{\star \star \star}\right)$ denote significance at the $10 \%, 5 \%$, and $1 \%$ levels, respectively.

Table 4. Impact of different situations of credit constraint (constrained borrower situations) on financial performance (gross sales) of small farmers

\begin{tabular}{lcccc}
\hline & \multicolumn{4}{c}{ Average Treatment Effects (ATT) } \\
\cline { 2 - 5 } Method & Treated (in \$) & Controls (in \$) & Difference (in \$) & $t$-stat \\
\hline Situation: Applied for agricultural loans, faced difficulty in the process (constrained borrowing 1) \\
\hline Nearest neighborhood matching (NNM) & $57,692.31$ & $39,846.15$ & $17,846.15$ & 0.72 \\
\hline Radius based matching (RBM) & $52,083.33$ & $48,979.59$ & $3,103.74$ & 0.26 \\
\hline Kernel based matching (KBM) & $55,357.14$ & $37,661.06$ & $17,696.08$ & 0.77 \\
\hline Situation: Did not get agricultural loans as required or desired level (constrained borrowing 2) & \\
\hline Nearest neighborhood matching (NNM) & 30,000 & $65,407.41$ & $-35,407.41^{\star \star *}$ & -2.42 \\
\hline Radius based matching (RBM) & $29,655.20$ & $63,409.09$ & $-33,409.09^{\star \star *}$ & -4.52 \\
\hline Kernel based matching (KBM) & $29,821.43$ & $69,013.42$ & $-39,191.99^{\star \star *}$ & -2.45 \\
\hline
\end{tabular}

Note: Asterisks $\left({ }^{*},{ }^{* \star}\right.$, and $\left.{ }^{\star * \star}\right)$ denote significance at the $10 \%, 5 \%$, and $1 \%$ levels, respectively.

farmers can be attributable to the reason farmers not being able to receive agricultural loans as required or desired level.

Overall summarizing our findings on impact, our ATT estimates from NNM, RBM, and KBM suggest that farmers who are credit constrained have gross sales around $\$ 20,000$ to $\$ 51,000$, below those who are credit unconstrained. Additionally, when further looking at the impact over specific situations within credit constraint, we found that constrained borrowers not able to obtain agricultural loans as required or desired level likely perform lower in gross sales-around $\$ 32,000$ to $\$ 39,000$ lower, as compared to unconstrained farmers. Overall our finding is consistent and comparable with Briggeman, Towe, and Morehart (2009), who found that ATT matched estimates of the impact of credit constraint on the value of farm sole proprietorship-production is around $-\$ 39,658$ using PSM Kernel-based matching. Using the same method, the estimated impact on crop specific value of production of sole proprietorship was estimated around $-\$ 53,955$. Acknowledging the difference in the nature of nation-wide data of farm sole proprietorship of Briggeman, Towe, and Morehart (2009) with our Tennessee specific small farm sample data, it is reasonable to claim that our results are comparable.

Our results indicate that mitigating the credit constraints and improving access to credit to credit-constrained small farmers and mitigating constrained borrowing by enabling agricultural loan borrowers to obtain loans fully at their required or desired level could enable them to achieve higher gross sales. Our impact results are consistent with our conceptual and theoretical model that derives the role of access to capital on financial performance. Finally, our findings are in support with some previous empirical studies that depict effects of credit constraints or the role of access to capital on farm household's efficiency, productivity, production, or economic/financial returns (Feder et al., 1990; Guirkinger and Boucher, 2008; Khanal and Regmi, 2018). 


\section{Discussion and conclusions}

We estimated factors influencing credit constraint and the impact of credit constraint on financial performance using an appropriate procedure based on the treatment effects method. To do so, we collected primary data by administering a survey to small farm households in Tennessee, following standard survey and sampling methods. Results from mean comparison and mean based estimators cannot be interpreted as the sole impact due to credit constraint as these methods do not account and control for several characteristic differences that are apparent between credit constrained and unconstrained farm households. To avoid this limitation, we used an innovative PSM estimator in this study, which overcomes this limitation by appropriately accounting for selection bias and heterogeneity. We computed impacts on financial performances (using gross sales as an indicator) that are attributable due to credit constraints of small farm households.

Using probit regression, we found the significant effects of gender, off-farm work participation, farm land acreage holdings, farm specialization/concentration, accessibility to a smartphone with Internet access, and farmers' satisfaction level about existing financing institutions in Tennessee on farmer's likelihood of credit constraint. Our results from the PSM estimator suggested that financial performances of credit constrained small farmers were significantly lower than unconstrained small farms - that is attributed to an adverse impact of constrained capacity to credit and capital and constrained borrowing.

The demand and use of credit by farmers is an effective tool in better financial performance. There is a corresponding ripple effect with increases in farm household income to the local and national economy if small farmers are able to improve their standard of living, increase disposable income, and continue farm production. Based on our findings, some mechanism to ease the credit access and lending process for agricultural loans for small farms irrespective of gender, land acreage holdings, and specialization help boost their financial performance. This study also found the importance of Internet access and off-farm work participation in making farmers less credit constrained. Hence, extension agents should engage and encourage farmers to use tools such as income diversification through off-farm jobs, and combating information asymmetry through the use of the Internet and smartphones to mitigate the adverse effects of capital constraints on financial performance. Additionally, inferences from our study also indicate that improving the capacity and method of agricultural lending in rural institutions may enhance credit access and financial performance of small farmers.

Acknowledgments. We thank two anonymous reviewers. Their comments have been helpful in shaping our paper.

Financial support. Principal author's time contribution in this study is supported by the Evans-Allen funds: TENX-1623GFSHPP, Accn\#1009664 and TENX-2031-GFSHPP, Accn\# 1021233. We acknowledge USDA/NIFA for the fund support.

\section{References}

Abadie, A., D. Drukker, J.L. Herr, and G.W. Imbens. "Implementing Matching Estimators for Average Treatment Effects in Stata." Stata Journal 4(2004):290-311.

Abadie, A., and G.W. Imbens. "Simple and Bias-corrected Matching Estimators for Average Treatment Effects." National Bureau of Economic Research (NBER) Technical Working Paper No. T0283, Cambridge, MA: NBER, 2002.

Abadie, A., and G.W. Imbens. "Bias-corrected Matching Estimators for Average Treatment Effects.” Journal of Business \& Economic Statistics 29,1(2011):1-11.

Adera, A. "Instituting Effective Linkages between Formal and Informal Financial Sector in Africa: A Proposal." Savings and Development 19,1(1995):5-22.

Ahma, W. "Meeting the Financial Needs of Smallholder Farmers in Ethiopia." African Smallholders. Food Crops, Markets and Policy. G. Djurfeldt, E. Aryeetey, and A. Isinika, eds. Wallingford, Oxfordshire, England: CAB International, 2010, pp. 156-88.

Akwaa-Sakyi, E.K. "Impact of Microcredit on Rural Farming Activities: The Case of Farming Communities within Sunyani Area." Management Science \& Engineering 7,4(2013):23-29.

Ali, D.A., K. Deininger, and M. Duponchel. "Credit Constraints, Agricultural Productivity, and Rural Nonfarm Participation: Evidence from Rwanda.” Policy Research Working Paper 6769, Development Research Work Group, The World Bank, 2014, p. 17. 
Ayamga, M., D.B. Sarpong, and S. Asuming-Brempong. "Factors Influencing the Decision to Participate in Micro-Credit Program: An Illustration for Northern Ghana." Ghana Journal of Development Studies 3,2(2006):57-65.

Barry, P.J., and L.J. Robison. "Agricultural Finance: Credit, Credit Constraints and Consequences." Handbook of Agricultural Economics. B. Gardner and G. Rausser, eds. Amsterdam: Elsevier, 2001, pp. 513-71.

Barrett, C.B., T. Reardon, and P. Webb. "Non-farm Income Diversification and Household Livelihood Strategies in Rural Africa: Concepts, Dynamics, and Policy Implications." Food Policy 26(2001):315-31.

Bembridge, T.J. "A Systems Approach Study of Agricultural Development Problems in Transkei." Ph.D. dissertation, University of Stellenbosch, Bloemfontein, South Africa, 1984.

Bethuel, K.K. "Credit Constraints and Agricultural Productivity in Developing Countries: The Case of East Africa." African Growth \& Development Policy (AGRODEP) Working Paper No. 0040, Dakar-Almadies Senegal and Washington, D.C.: AGRODEP, 2018.

Binswanger, H.P., and K. Deininger. "Explaining Agricultural and Agrarian Policies in Developing Countries." Journal of Economic Literature 35,4(1997):1958-2005.

Blancard, S., J. Boussemart, W. Briec, and K. Kerstens. "Short- and Long-Run Credit Constraints in French Agriculture: A Directional Distance Function Framework Using Expenditure-Constrained Profit Functions.” American Journal of Agricultural Economics 88,2(2006):351-64.

Boucher, S.R., C. Guirkinger, and C. Trivelli. "Direct Elicitation of Credit Constraints: Conceptual and Practical Issues with an Application to Peruvian Agriculture." Economic Development and Cultural Change 57,4(2009):609-40.

Briggeman, B.C., C.A. Towe, and M.J. Morehart. "Credit Constraints: Their Existence, Determinants, and Implications for U.S. Farm and Nonfarm Sole Proprietorships.” American Journal of Agricultural Economics 91,1(2009):275-89.

Cameron, A.C., and P.K. Trivedi. Microeconometrics Using Stata. Vol. 2. College Station, TX: Stata Press, 2010.

Carter, M.R. “Equilibrium Credit Rationing of Small Farm Agriculture.” Journal of Developing Economies 28(1988):83-103.

Census of Agriculture, 2017. Internet site: https://www.nass.usda.gov/Quick_Stats/ (Accessed August 2019).

Conning, J., and C. Udry. Rural Financial Markets in Developing Countries: The Handbook of Agricultural Economics. Vol. 3. North-Holland: Elsevier, 2005.

Dehejia, R.H., and S. Wahba. "Propensity Score-Matching Methods for Non-Experimental Causal Studies." Review of Economics and Statistics 84,1(2002):151-61.

Dercon, S. "Risk, Crop Choice and Savings: Evidence from Tanzania." Economic Development and Cultural Change 44,3(1996):485-513.

Dicken, P. Global Shift: Mapping the Changing Contours of the World Economy. London, California, New Delhi: SAGE Publications Inc., 2007.

Dillman, D.A. “The Design and Administration of Mail Surveys." Annual Review of Sociology 171(1991):225-49.

Dillman, D.A., J.D. Smyth, and L.M. Christian. Internet, Mail, and Mixed Mode Surveys: The Tailored Design Method. 3rd ed. Hoboken, NJ: Wiley, 2009.

Dlova, M.R., G.C. Fraser, and A. Belete. "Factors Affecting the Success of Farmers in the Hertzog Agricultural Cooperative in the Central Eastern Cape." Fort Hare Papers 13(2004):21-33.

Dodson, C.B., and B.L. Ahrendsen. "Structural Change Implies Unique Role for Federal Credit." Choices 31,1(2016):1-10.

Dodson, C.B., and B.L. Ahrendsen. "Farm and Lender Structural Change: Implications for Federal Credit." Agricultural Finance Review 77,1(2017):78-94.

Dowd, K. “Optimal Financial Contract." Oxford Economic Papers 44(1992):672-93.

Eswaran, M., and A. Kotwal. "Implications of Credit Constraints for Risk Behavior in Less Developed Economies." Oxford Economic Papers 42,2(1990):473-82.

Färe, R., S. Grosskopf, and H. Lee. "A Nonparametric Approach to Expenditure Constrained Profit Maximization." American Journal of Agricultural Economics 72(1990):574-81.

Farm Credit System (FCS), 2016. Internet site: https://www.fca.gov/ (Accessed December 2018).

Farm Sector Balance Sheet, United States Department of Agriculture, Economic Research Service (USDA, ERS), 2019. Internet site: https://data.ers.usda.gov/reports.aspx?ID=17835 (Accessed July 2019).

Feder, G., L. Lau, J. Lin, and X. Luo. "The Relationship between Credit and Productivity in Chinese Agriculture: A Microeconomic Model of Disequilibrium.” American Journal of Agricultural Economics 72,5(1990):1151-57.

Fletschner, D., C. Guirkinger, and S. Boucher. "Risk, Credit Constraints and Financial Efficiency in Peruvian Agriculture." Journal of Development Studies 46,6(2010):981-1002.

Girante, M.J., B.K. Goodwin, and A. Featherstone. "Farmers' Crop Acreage Decisions in the Presence of Credit Constraints: Do Decoupled Payments Matter?” Selected paper 469488, Agricultural \& Applied Economics Association 2008 Annual Meetings, Orlando, Florida, July 27-29, 2008.

Guirkinger, C. "Understanding the Coexistence of Formal and Informal Credit Markets in Piura, Peru." World Development 36,8(2008):1436-52.

Guirkinger, C., and S.R. Boucher. "Credit Constraints and Productivity in Peruvian Agriculture." Agricultural Economics 39,3(2008):295-308. 
Gujarati, D.N. Basic Econometrics. Noida, India: Tata McGraw-Hill Education, 2009.

Harris, J.M., J. Johnson, J. Dillard, R. Williams, and R. Dubman. The Debt Finance Landscape for US Farming and Farm Businesses. Washington, D.C.: US Department of Agriculture, Economic Research Services Technical Research Bulletin AIS-87, 2009.

Hartarska, V., and D. Nadolnyak. "Financing Constraints and Access to Credit in a Post-Crisis Environment: Evidence from New Farmers in Alabama. Journal of Agricultural and Applied Economics 44,4(2012):607-21.

Hartarska, V., D. Nadolnyak, and X. Shen. "Agricultural Credit and Economic Growth in Rural Areas." Agricultural Finance Review 75,3(2015):302-12.

Imbens, G.W. "Nonparametric Estimation of Average Treatment Effects under Exogeneity: A Review." Review of Economics and Statistics 86,1(2004):4-29.

Jappelli, T. "Who Is Credit Constrained in the US Economy?" Quarterly Journal of Economics 105,1(1990):219-34.

Johnson, J. "Rural Economic Development in the United States: An Evaluation of the US Department of Agriculture's Business and Industry Guaranteed Loan Program.” Economic Development Quarterly 23,3(2009):229-41.

Joo, H., A.R. Khanal, and A.K. Mishra. "Farmers' Participation in Agritourism: Does it Affect the Bottom Line?" Agricultural and Resource Economics Review 42,3(2014):471-90.

Khanal, A.R., and A.K. Mishra. "Financial Performance of Small Farm Business Households: The Role of Internet." China Agricultural Economic Review 8,4(2016):553-71.

Khanal, A.R., A.K. Mishra, and K.H. Koirala. "Access to the Internet and Financial Performance of Small Business Households.” Electronic Commerce Research 15,2(2015):159-75.

Khanal, A.R., and M. Regmi. "Financial Constraints and Production Efficiency: A Case from Rice Growers in Drought Prone Areas.” Agricultural Finance Review 78,1(2018):25-40.

Kilkenny, M., and R.W. Jolly. "Are Rural Credit Markets Competitive? Is there Room for Competition in Rural Credit Markets?” Choices 20,1(2005):25-29.

Lee, H., and R.G. Chambers. "Expenditure Constraints and Profit Maximization in US Agriculture." American Journal of Agricultural Economics 68(1986):857-65.

Mendola, M. “Agricultural Technology Adoption and Poverty Reduction: A Propensity Score Matching Analysis for Rural Bangladesh.” Food Policy 32,3(2007):372-93.

Mishra, A.K., C.B. Moss, and K.W. Erickson. "The Role of Credit Constraints and Government Subsidies in Farmland Valuations in the US: An Options Pricing Model Approach.” Empirical Economics 34,2(2008):285-97.

Nadolnyak, D., X. Shen, and V. Hartarska. "Farm Income and Output and Lending by the Farm Credit System." Agricultural Finance Review 77,1(2017):125-36.

Ojiako, I.A., and B.C. Ogbukwa. "Economic Analysis of Loan Repayment Capacity of Smallholder Cooperative Farmers in Yewa North Local Government Area of Ogun State, Nigeria." African Journal of Agricultural Research 7,13(2012):2051-62.

Petrick, M. "Empirical Measurement of Credit Rationing in Agriculture: A Methodological Survey." Agricultural Economics 33,2(2005):191-203.

Reardon, T., E. Crawford, and V. Kelly. "Links between Nonfarm Income and Farm Investment in African Households: Adding the Capital Market Perspective." American Journal of Agricultural Economics 76,5(1994):1172-76.

Rosenbaum, P.R., and D.B. Rubin. "Reducing Bias in Observational Studies Using Sub Classification on the Propensity Score." Journal of the American Statistical Association 79(1984):516-24.

Rosenbaum, P.R., and D.B. Rubin. "Constructing a Control Group Using Multivariate Matched Sampling Methods That Incorporate the Propensity Score." American Statistician 39,1(1985):33-38.

Rubin, D.B. "For Objective Causal Inference, Design Trumps Analysis.” Annals of Applied Statistics 2,3(2008):808-40.

Sianesi, B. "An Evaluation of the Swedish System of Active Labor Market Programs in The 1990s." Review of Economics and Statistics 86,1(2004):133-55.

Sitienei, I., A.K. Mishra, and A.R. Khanal. "Informal ‘Ganyu' Labor Supply, and Food Security: The Case of Malawi." Food Security in a Food Abundant World: An Individual Country Perspective. Bingley, U.K.: Emerald Group Publishing Limited, 2016, pp. 159-75.

Stiglitz, J.E., and A. Weiss. "Credit Rationing in Markets with Imperfect Information." American Economic Review 71,3(1981):393-410.

Tauer, L.W., and H.M. Kaiser. "Negative Milk Supply Response under Constrained Profit Maximizing Behavior." Northeastern Journal of Agricultural and Resource Economics 17,2(1988):111-17.

Tennessee Farm Bureau, 2019. Internet site: https://www.tnfarmbureau.org/tennessee-farm-facts (Accessed July 2019).

Turvey, C.G. "Historical Developments in Agricultural Finance and the Genesis of America's Farm Credit System." Agricultural Finance Review 77,1(2017):4-21.

Uematsu, H., and A.K. Mishra. "Organic Farmers or Conventional Farmers: Where's the Money?" Ecological Economics 78(2012):55-62.

United States Department of Agriculture, Economic Research Service (USDA/ERS), 2017. Internet site: https://www.ers. usda.gov/ (Accessed June 2019). 
Verhofstadt, E., and M. Maertens. "Can Agricultural Cooperatives Reduce Poverty? Heterogeneous Impact of Cooperative Membership on Farmers' Welfare in Rwanda.” Applied Economic Perspectives and Policy 37,1(2014):86-106.

Von Pischke, J.D. Finance at the Frontier: Debt Capacity and the Role of Credit in the Private Economy. Washington, D.C.: The World Bank, 1991.

Whittaker, G.W., and M.J. Morehart. "Measuring the Effect of Farm Financial Structure on Cost Efficiency." Agricultural Finance Review 51(1991):95-105.

\section{Appendix}

Table A1. Test for selection bias after matching

\begin{tabular}{|lcccccc}
\hline & \multicolumn{2}{c}{$\begin{array}{c}\text { Matched Sample } \\
\text { Mean }\end{array}$} & & & \\
Variable & Treated & Control & & \% Bias & $\begin{array}{c}\text { \% Bias } \\
\text { Reduction }\end{array}$ & $\begin{array}{c}P \text { value } \\
\text { from } t \text {-test }\end{array}$ \\
\cline { 2 - 5 } Age of primary operator & 53 & 53.775 & -7.8 & 40.1 & 0.832 \\
\hline Education of primary operator & 13.75 & 13.713 & 1.3 & 77.5 & 0.975 \\
\hline Gender of primary operator: Male & 0.813 & 0.837 & -6.0 & 93.2 & 0.858 \\
\hline Household income, in log & 11.115 & 11.097 & 1.8 & 92.8 & 0.928 \\
\hline Agricultural land acres & 2.888 & 3.184 & -12.5 & 67.1 & 0.615 \\
\hline Off-farm work & 0.5 & 0.5 & 0.0 & 100.0 & 1.000 \\
\hline Smartphone with internet access & 0.812 & 0.85 & -10.1 & 71.7 & 0.786 \\
\hline Continuation plan & 0.875 & 0.95 & -19.6 & -18.0 & 0.469 \\
\hline Specialized operation & 0.625 & 0.625 & 0.0 & 100.0 & 1.000 \\
\hline Ag enterprise diversity score & 2.562 & 2.737 & -13.1 & 21.1 & 0.746 \\
\hline Risk perception & 2.812 & 2.95 & -13.0 & 5.7 & 0.722 \\
\hline
\end{tabular}

Table A2. Statistical test to evaluate bias-reduction after matching

\begin{tabular}{lccccc}
\hline Matching Method & $\begin{array}{c}\text { Pseudo } \\
R^{2}\end{array}$ & $\begin{array}{c}\text { Likelihood } \\
\text { Ratio } \chi^{2}\end{array}$ & $P>\chi^{2}$ & $\begin{array}{c}\text { Mean } \\
\text { Bias }\end{array}$ & $\begin{array}{c}\text { Median } \\
\text { Bias }\end{array}$ \\
\hline Before matching & 0.410 & 40.43 & 0.000 & 36.6 & 27.3 \\
\hline Nearest neighbor matching (NNM) & 0.056 & 2.51 & 0.998 & 7.9 & 6.9 \\
\hline Kernel based matching (KBM) & 0.049 & 2.20 & 0.999 & 8.8 & 6.8 \\
\hline Radius based matching (RBM) & 0.120 & 2.69 & 0.997 & 15.3 & 18.1 \\
\hline
\end{tabular}

Cite this article: Khanal AR and Omobitan O (2020). Rural Finance, Capital Constrained Small Farms, and Financial Performance: Findings from a Primary Survey. Journal of Agricultural and Applied Economics 52, 288-307. https:// doi.org/10.1017/aae.2019.45 